\title{
Life Cycle Carbon Footprint Analysis of Pulp and Paper Grades in the United States Using Production-line-based Data and Integration
}

\begin{abstract}
Kristen E. Tomberlin, Richard Venditti,* and Yuan Yao *
Greenhouse gas (GHG) emission levels are causing concern as climate change risks are growing, emphasizing the importance of $\mathrm{GHG}$ research for better understanding of emission sources. Previous studies on GHG emissions for the pulp and paper industry have ranged in scope from global to regional to site-specific. This study addresses the present knowledge gap of how GHG emissions vary among paper grades in the US. A cradle-to-gate life cycle carbon analysis for 252 mills in the US was performed by integrating large datasets at the production line level. The results indicated that one metric ton of paper product created a production weighted average of $942 \mathrm{~kg}$ of carbon dioxide equivalent $\left(\mathrm{kg} \mathrm{CO}_{2} \mathrm{eq}\right)$ of GHG emissions. Greenhouse gas emissions varied by pulp and paper grade, from $608 \mathrm{~kg} \mathrm{CO}_{2} \mathrm{eq}$ per metric ton of product to $1978 \mathrm{~kg} \mathrm{CO}_{2} \mathrm{eq}$ per metric ton of product. Overall, fuels were the greatest contributor to the GHG emissions and should be the focus of emission reduction strategies across pulp and paper grades.
\end{abstract}

Keywords: Greenhouse gas; Carbon footprint; Cradle to gate; Life cycle assessment

Contact information: Department of Forest Biomaterials, North Carolina State University, Campus Box 8005, Raleigh, NC 27695-8005, USA;

*Corresponding authors: richard_venditti@ncsu.edu; yuan_yao@ncsu.edu

\section{INTRODUCTION}

In 2018, the Intergovernmental Panel on Climate Change (IPCC) published a special report on the impacts of global warming at $1.5{ }^{\circ} \mathrm{C}$ above pre-industrial levels, including various greenhouse gas (GHG) reduction pathways and strategies (MassonDelmotte et al. 2018). They predicted that this level of warming will occur by 2040 (Masson-Delmotte et al. 2018). At $2{ }^{\circ} \mathrm{C}$ above pre-industrial levels, loss in biodiversity and severe flooding risks increase for coastal regions (Masson-Delmotte et al. 2018). This mark, however, can still be prevented, making GHG research critical, as it provides a basis for identifying effective GHG reduction strategies.

Industries worldwide are responsible for $21 \%$ of global GHG emissions (Fischedick et al. 2014). The US pulp and paper industry produced 84.4 million metric tons of products in 2018 (Fisher International 2018). Globally, the paper industry produced approximately 400 million metric tons of products in 2018 and is steadily growing, with increasing production of packaging, tissue, and other specialty grades (RISI 2018).

Previous GHG research on the paper industry mainly falls into two general categories: large-scale studies and life cycle assessments (LCA). Large-scale studies cover global or regional industries and can vary in level of detail reported. For example, the Fifth Assessment Report of the IPCC gathered GHG data on global industries and focused on mitigation strategies (Fischedick et al. 2014). This report emphasized the GHG reduction

Tomberlin et al. (2020). "Pulp \& paper GHG emissions," BioResources 15(2), 3899-3914. 3899 
potential of energy efficiency improvements in the pulp and paper industry (Fischedick et al. 2014). The US Environmental Protection Agency (EPA) has published direct GHG emissions data for all major US industries, including pulp and paper (EPA 2017). This program, the Greenhouse Gas Reporting Program, reported 35.5 million metric tons of $\mathrm{CO}_{2}$ eq from the US pulp and paper industry in 2017 (EPA 2017), which equates to $403 \mathrm{~kg}$ $\mathrm{CO}_{2}$ eq per metric ton of product.

Most environmental LCAs focus on a single product, site, or manufacturing line and track the emissions and other environmental impact factors. The purposes of these studies vary and include internal use for production facilities to assess a process or to compare two or more alternative products that are made with different processes or materials. For example, a comparative LCA comparing recycled paper and polystyrene for egg packaging (Zabaniotou and Kassidi 2003) provided carton manufacturers and consumers the ability to make more informed decisions. The American Forest and Paper Association, along with the Forest Products Association of Canada, used an LCA to provide a benchmark for industry (AF\&PA 2011). This LCA calculated that one metric ton of coated/uncoated mechanical and wood-free papers generates between $1300 \mathrm{~kg} \mathrm{CO} 2 \mathrm{eq}$ and $1600 \mathrm{~kg} \mathrm{CO} 2 \mathrm{eq}$ (AF\&PA 2011).

Current large-scale studies lack the depth to provide reduction strategies that may apply to different types of mills. Meanwhile, LCAs take great amounts of time and resources to perform, and it is often impractical to cover each mill in the US with traditional LCA methods. To fill the gap, this study sought to better understand the GHG breakdown within the US pulp and paper industry by creating a model based on self-reported mill data and data-mined emission factors (Tomberlin 2019). Using this data, most production lines in the United States (in total, 865 production lines) were assessed. Each product line was separated into one of eleven product categories, and the industry averages and distributions for the individual products were determined. This allowed for more in-depth analysis of noteworthy sources of emissions and areas of focus for emission reductions on an industrywide product-by-product basis.

\section{EXPERIMENTAL}

\section{Scope}

The mill data used in this study were sourced from FisherSolve (Fisher International 2018), a global pulp and paper mill database that combines self-reported and data-mined information on the inputs and outputs of mills. This research used 2018 data for operating US pulp and paper mills that reported a finished product. Less than $1 \%$ of mills, by production volume, were excluded due to incomplete data. Names of mills were removed for anonymity. Note that the production process, raw material combination, and energy consumption of different types of paper products are different. Such differences were considered by using mill- and production-line-specific process data collected from FisherSolve.

This study follows the ISO standard 14040 series for LCA (ISO, 2006). The system boundary of this study is cradle-to-gate, including wood procurement (from the harvest of logs), the upstream production of other materials such as fuels, electricity, and chemicals, transportation of those materials to mill, and pulp and paper production. GHG emissions generated from all of those activities were tracked and analyzed, with details discussed as follows. 


\section{Equations}

Three types of GHG were included in this study, $\mathrm{CO}_{2}, \mathrm{CH}_{4}$, and $\mathrm{N}_{2} \mathrm{O}$, which are major GHG emissions from the pulp and paper industry (Nabinger et al. 2019). GHG other than $\mathrm{CO}_{2}$ were converted to $\mathrm{CO}_{2}$ eq based on their global warming potential (GWP) characterization factors (Eq. 1), based on the latest IPCC report (Myhre et al. 2013).

$$
\mathrm{kg} \mathrm{CO}_{2 e q, \text { fossil }}=1\left(\mathrm{kgCO}_{2}\right)+30\left(\mathrm{~kg} \mathrm{CH}_{4, \text { fossil }}\right)+265\left(\mathrm{~kg} \mathrm{~N}_{2} \mathrm{O}\right)
$$

Equation 2 was used to calculate biogenic $\mathrm{CO}_{2} \mathrm{eq}$ emissions from the combustion of biomass; direct oxidation of biomass generating $\mathrm{CO}_{2}$ was not considered as part of the total GHG emissions. Biogenic $\mathrm{CO}_{2}$ was separately tracked for each mill because there are some discussions on how it should be accounted for in GWP studies. Some studies have used the carbon-neutral assumption for biogenic $\mathrm{CO}_{2}$, and thus the characterization factor for the GWP of biogenic $\mathrm{CO}_{2}$ is zero (Ishikawa et al. 2006; Zhang et al. 2013). Other studies have indicated the potential impacts of biogenic $\mathrm{CO}_{2}$ when the dynamics of biomass and climate systems are accounted (Bright et al. 2012; Cherubini et al. 2012; Levasseur et al. 2012; Daystar et al. 2017). Biogenic $\mathrm{CO}_{2}$ was separately tracked herein, so the results can be used by researchers and analysts for future research using different accounting models.

$$
\mathrm{kg} \mathrm{CO}_{2 e q}=28\left(\mathrm{~kg} \mathrm{CH}_{4, \text { bio }}\right)+265\left(\mathrm{~kg} \mathrm{~N}_{2} \mathrm{O}\right)
$$

Two terms were used to describe GHG emissions in this study: total GHG emissions ( $\mathrm{kg} \mathrm{CO}_{2} \mathrm{eq}$ ) and $\mathrm{GHG}$ intensity (GHGI, $\mathrm{kg} \mathrm{CO}_{2} \mathrm{eq} /$ metric ton of product). Total GHG emissions included $\mathrm{CO}_{2}$ eq from all sources (Eq. 3), while GHGI also included all sources of $\mathrm{CO}_{2} \mathrm{eq}$ but per metric ton of product (Eq. 4),

$$
\begin{aligned}
& G H G_{\text {total }}=\sum E F i \\
& G H G I=G H G_{\text {total }} / P
\end{aligned}
$$

where $i$ is an input ( $\mathrm{kg}, \mathrm{J}$, or $\mathrm{W} \cdot \mathrm{h})$ of a mill, $E F i$ is the respective input's emission factor (kg CO 2 eq per input unit), and $P$ is the total annual product production (metric tons / year). If the input is a fuel, the emission factor includes both on-site and embodied GHG emissions. If the input is a material (e.g., chemicals), the emission factor is for embodied GHG emissions, i.e., cradle-to-gate emissions.

\section{Standards}

Pulp and paper products were grouped according to the TAPPI TIP 0404-36 (2013) reference, Table 1 . The abbreviations will be used in all tables and figures.

\section{Emission Factors}

Emission factors were derived from many sources to best fit the system boundary of this study. There were 120 emission factors documented (Tables 2 to 6 ), and most were given in units of $\mathrm{kg} \mathrm{CO}_{2}$ eq per unit $(\mathrm{kg}$, J, or $\mathrm{W} \cdot \mathrm{h})$ or converted into the needed unit as required. Electricity emission factors were collected from the EPA's eGRID database based on each mill's state (EPA 2016). Note that such emission factors were only used for electricity purchased from the grid. 
Table 1. Paper Product Categories with Abbreviations and Definitions (TAPPI TIP 0404-36 2013)

\begin{tabular}{|c|c|c|}
\hline Category Name & Abbreviation & Definition \\
\hline Uncoated ground wood & UCGW & $\begin{array}{c}\text { Product made with mechanically separated } \\
\text { fibers }\end{array}$ \\
\hline Coated ground wood & CGW & $\begin{array}{c}\text { Coated product made with mechanically } \\
\text { separated fibers }\end{array}$ \\
\hline Uncoated wood free & UCWF & Chemically pulped paper without coating \\
\hline Coated wood free & CWF & Chemically pulped paper with coating \\
\hline Packing paper & PP & $\begin{array}{c}\text { Kraft papers used for packing, bleached or } \\
\text { unbleached, and including papers with } \\
\text { machine-glaze finishes }\end{array}$ \\
\hline Bleached paperboard & BPB & Paperboard with a bleached furnish \\
\hline Unbleached paperboard & UBPB & $\begin{array}{c}\text { Paperboard made with virgin fibers, without } \\
\text { a bleached furnish }\end{array}$ \\
\hline Recycled paperboard & RPB & Paperboard made with recovered fibers \\
\hline Tissue & Tissue & $\begin{array}{c}\text { Lightweight paper mostly used for sanitary } \\
\text { products }\end{array}$ \\
\hline Market pulp & MP & All pulps produced to be sold \\
\hline Others & Others & $\begin{array}{c}\text { Specialty papers that do not fit into any } \\
\text { other category }\end{array}$ \\
\hline
\end{tabular}

The emissions associated with electricity generated on-site were calculated based on the emission factors of specific fuels (shown in Table 2) and mill-level fuel consumption data collected from FisherSolve (Fisher International 2018). Emission factors for the various modes of transport (Table 5) were used with the Bureau of Transportation Statistics and the U.S. Census Bureau's 2012 Commodity Flow Survey estimated distances for each input that was shipped to the mill site (BTS and U.S. Census Bureau 2015) as shown in Table 6. Ideally, the emission factors of electricity and transportation could be differentiated at the mill level by tracking individual source of electricity and transportation activities. However, such analysis is extremely challenging given the highly complex and integrated electricity grid and transportation networks.

Table 2 documents the GHG emission factors for fuels used by the U.S. pulp and paper industry in 2018. Combustion emission factors include GHG emissions generated from burning fuels. For each fuel, the pre-combustion emission factor includes the total GHG emissions generated from raw material extraction, fuel production, and transportation to the mills (in other words, cradle-to-gate GHG emissions). Fuels that are wastes or internally generated (e.g., pulping liquor, railroad ties, and sludge) are assumed to be burden free, therefore their pre-combustion emission factors are zero. In addition, the emission factors of steam were only collected for the steam purchased from outside sources as shown in Table 2. The GHG emissions of steam generated on-site (e.g., through combined heat and power) were calculated based on the fuel consumption collected from FisherSolve and emission factors of specific fuels (that were used to generate steam) in Table 2.

Table 4 lists the cradle to gate GHG emission factors of chemicals used in the U.S. pulp and paper industry. The chemical type (first column) indicates the specific unit process where each chemical is used. For example, chlorine is used in pulp bleaching, thus the chemical type is marked as bleaching in Table 4. 
Table 2. GHG Emission Factors for Fuels Used by the US Pulp and Paper Industry in 2018 (EPA 2018)

\begin{tabular}{|c|c|c|c|c|c|}
\hline \multirow[b]{2}{*}{ Fuel } & \multirow{2}{*}{$\begin{array}{c}\text { Pre- } \\
\text { combustion } \\
\text { Emission } \\
\text { Factor (kg } \\
\mathrm{CO}_{2} \text { eq / GJ) }\end{array}$} & \multicolumn{4}{|c|}{ Combustion Emission Factors } \\
\hline & & $\begin{array}{c}\text { Carbon } \\
\text { Dioxide } \\
\left(\mathrm{kg} \mathrm{CO}_{2} / \mathrm{GJ}\right)\end{array}$ & $\begin{array}{c}\text { Methane }(\mathrm{kg} \\
\mathrm{CH}_{4} / \mathrm{GJ}\end{array}$ & $\begin{array}{c}\text { Nitrous } \\
\text { Oxide } \\
\left(\mathrm{kg} \mathrm{N} \mathrm{N}_{2} \mathrm{O}\right. \\
\mathrm{GJ})\end{array}$ & $\begin{array}{c}\text { Total GHG } \\
\text { (kg COneq } \\
\text { / GJ) }\end{array}$ \\
\hline Biodiesel & 0.002 & $70.0^{*}$ & $1.04 \times 10^{-3}$ & $1.04 \times 10^{-4}$ & 0.06 \\
\hline Biogas & 2.890 & $49.4^{*}$ & $3.03 \times 10^{-3}$ & $5.97 \times 10^{-4}$ & 0.25 \\
\hline $\begin{array}{c}\text { Compressed } \\
\text { natural gas (CNG) }\end{array}$ & 0.017 & 50.3 & $9.48 \times 10^{-4}$ & $9.48 \times 10^{-5}$ & 50.3 \\
\hline Coal & 6.120 & 89.7 & $1.04 \times 10^{-2}$ & $1.52 \times 10^{-3}$ & 90.4 \\
\hline Natural gas & 0.009 & 50.3 & $9.48 \times 10^{-4}$ & $9.48 \times 10^{-5}$ & 50.3 \\
\hline $\begin{array}{l}\text { Liquefied natural } \\
\text { gas (LNG) }\end{array}$ & 0.008 & 50.3 & $9.48 \times 10^{-4}$ & $9.48 \times 10^{-5}$ & 50.3 \\
\hline Methanol & 0.004 & $67.9^{*}$ & 0.00 & 0.00 & 0.00 \\
\hline Number 2 oil & 0.013 & 70.1 & $2.84 \times 10^{-3}$ & $5.69 \times 10^{-4}$ & 70.3 \\
\hline Number 6 oil & 0.013 & 71.2 & $2.84 \times 10^{-3}$ & $5.69 \times 10^{-4}$ & 71.4 \\
\hline Petcoke & 0.034 & 97.1 & $2.84 \times 10^{-3}$ & $5.69 \times 10^{-4}$ & 97.3 \\
\hline Pulping liquor & 0.00 & $89.1^{*}$ & $1.80 \times 10^{-3}$ & $3.98 \times 10^{-4}$ & 0.16 \\
\hline Railroad ties & 0.00 & $88.9^{*}$ & $6.82 \times 10^{-3}$ & $3.41 \times 10^{-3}$ & 1.11 \\
\hline $\begin{array}{l}\text { Refuse-derived } \\
\text { fuel (RDF) }\end{array}$ & 0.00 & 86.0 & $3.03 \times 10^{-3}$ & $5.97 \times 10^{-4}$ & 86.2 \\
\hline Recycled fuel oil & 0.00 & 70.1 & $2.84 \times 10^{-3}$ & $5.69 \times 10^{-4}$ & 70.3 \\
\hline Sludge & 0.00 & $88.9^{*}$ & $6.82 \times 10^{-3}$ & $3.41 \times 10^{-3}$ & 1.11 \\
\hline Steam purchases & 0.086 & 62.9 & $1.18 \times 10^{-3}$ & $1.18 \times 10^{-4}$ & 62.9 \\
\hline Tires & 0.00 & 81.5 & $3.03 \times 10^{-2}$ & $4.08 \times 10^{-3}$ & 83.4 \\
\hline Waste wood & 0.00 & $88.9^{*}$ & $6.82 \times 10^{-3}$ & $3.41 \times 10^{-3}$ & 1.11 \\
\hline
\end{tabular}

* Biogenic carbon dioxide sources are marked and were excluded from the total GHG emission factor and total annual GHG emissions.

Since this study covers a large number of pulp and paper mills across the United States, not all chemicals listed in Table 4 are used in each individual mill. Instead, Table 4 is a comprehensive list of all chemicals used in pulp and paper mills that have different process configurations, products, and feedstocks.

Table 3. Upstream Emission Factors for Wood Procurement (National Renewable Energy Laboratory 2015)

\begin{tabular}{|c|c|}
\hline Wood Type & GHG Emission Factor $(\mathrm{kg} \mathrm{CO}$ eq / kg dry basis) \\
\hline Northern hardwood chips & 0.22 \\
\hline Northern hardwood logs & 0.05 \\
\hline Northern softwood chips & 0.22 \\
\hline Northern softwood logs & 0.05 \\
\hline Northern softwood sawdust & 0.12 \\
\hline Southern hardwood chips & 0.09 \\
\hline
\end{tabular}


Table 4. Upstream (Cradle-to-gate) GHG Emission Factors for Chemicals Used by the US Pulp and Paper Industry

\begin{tabular}{|c|c|c|c|}
\hline $\begin{array}{l}\text { Chemical } \\
\text { Type }\end{array}$ & Chemical Name & $\begin{array}{c}\text { GHG Emission Factor } \\
\text { (kg CO } \mathrm{kO}_{2} \mathrm{eq} / \mathrm{kg} \text { dry basis) }\end{array}$ & Reference \\
\hline \multirow{10}{*}{ Bleaching } & Chlorine & 1.07 & \multirow{10}{*}{ Wernet et al. (2016) } \\
\hline & Hydrogen peroxide & 1.18 & \\
\hline & Methyl alcohol & 0.18 & \\
\hline & Oxygen & 0.11 & \\
\hline & Ozone & 6.52 & \\
\hline & Sodium chlorate & 0.40 & \\
\hline & Sodium chloride & 0.28 & \\
\hline & Sodium hydrosulfite & 3.85 & \\
\hline & Sodium hypochlorite & 0.96 & \\
\hline & Sulfuric acid & 0.16 & \\
\hline \multirow{10}{*}{ Pulping } & Ammonium & 2.89 & \multirow{10}{*}{ Wernet et al. (2016) } \\
\hline & Calcium carbonate & 1.45 & \\
\hline & Caustic soda & 1.35 & \\
\hline & Lime & 1.14 & \\
\hline & Magnesium sulfate & 0.24 & \\
\hline & Sodium carbonate & 0.52 & \\
\hline & Sodium sulfate & 0.51 & \\
\hline & Sodium sulfite & 1.50 & \\
\hline & Sodium sulfide & 3.04 & \\
\hline & Sulfur & 0.23 & \\
\hline \multirow{5}{*}{$\begin{array}{l}\text { Pigment } \\
\text { Filler }\end{array}$} & Clay & 0.001 & \multirow{3}{*}{ Wernet et al. (2016) } \\
\hline & GCC & 0.02 & \\
\hline & PCC & 0.32 & \\
\hline & Talc & 0.01 & EPA (1995) \\
\hline & Titanium dioxide & 4.60 & Wernet et al. (2016) \\
\hline \multirow{5}{*}{$\begin{array}{l}\text { Pigment } \\
\text { Coating }\end{array}$} & Clay & 0.001 & \multirow{3}{*}{ Wernet et al. (2016) } \\
\hline & GCC & 0.02 & \\
\hline & PCC & 0.32 & \\
\hline & Synthetic pigments & 0.78 & $\begin{array}{c}\text { National Renewable } \\
\text { Energy Labratory (2015) }\end{array}$ \\
\hline & Titanium dioxide & 4.60 & Wernet et al. (2016) \\
\hline $\begin{array}{l}\text { Pulping } \\
\text { Mineral }\end{array}$ & Talc & 0.01 & EPA (1995) \\
\hline \multirow{5}{*}{ Wet End } & Alkaline size & 3.50 & Triantou (2009) \\
\hline & Alum & 0.57 & \multirow{4}{*}{ Wernet et al. (2016) } \\
\hline & Retention aid PAM & 2.78 & \\
\hline & Rosin size & 1.63 & \\
\hline & Wet-end starch & 0.97 & \\
\hline \multirow{2}{*}{ Paper Dyes } & Dyes & 0.78 & \multirow{2}{*}{$\begin{array}{c}\text { National Renewable } \\
\text { Energy Labratory }(2015)\end{array}$} \\
\hline & Dyes, FWA & 0.78 & \\
\hline \multirow{3}{*}{$\begin{array}{l}\text { Paper } \\
\text { Other }\end{array}$} & Creping aid & 2.06 & \multirow{3}{*}{ Wernet et al. (2016) } \\
\hline & Dry strength & 1.84 & \\
\hline & Wet strength & 2.29 & \\
\hline \multirow{3}{*}{$\begin{array}{l}\text { Paper } \\
\text { Coating }\end{array}$} & Coating starch & 0.97 & \multirow{3}{*}{ Wernet et al. (2016) } \\
\hline & Latex & 2.62 & \\
\hline & Size press starch & 0.97 & \\
\hline Recycling & Deinked chemicals & 0.87 & Wernet et al. (2016) \\
\hline
\end{tabular}

GCC - ground calcium carbonate; PCC - precipitated calcium carbonate; PAM - polyacrylamide;

FWA - fluorescent whitening agents 
Table 5. GHG Emission Factors for Transportation Methods (EPA 2018)

\begin{tabular}{|c|c|}
\hline Method & GHG Emission Factor $(\mathrm{kg} \mathrm{CO}$ eq / (metric ton $\cdot \mathrm{km}))$ \\
\hline $\begin{array}{c}\text { Truck (medium- and heavy- } \\
\text { duty) }\end{array}$ & 0.139 \\
\hline Rail & 0.016 \\
\hline Water & 0.041 \\
\hline Air & 0.903 \\
\hline
\end{tabular}

Table 6. Distances and Percent-by-weight Distributions for Transportation of Materials Going to US Pulp and Paper Mills (BTS and U.S. Census Bureau 2015)

\begin{tabular}{|c|c|c|c|c|c|c|c|c|c|}
\hline $\begin{array}{c}\text { Commodity } \\
\text { Type }\end{array}$ & $\begin{array}{c}\text { Total } \\
\text { Average } \\
\text { Distance } \\
(\mathrm{km})\end{array}$ & $\begin{array}{c}\text { Truck } \\
(\mathrm{km})\end{array}$ & $\begin{array}{c}\text { Truck \% } \\
\text { by } \\
\text { Weight }\end{array}$ & $\begin{array}{c}\text { Rail } \\
(\mathrm{km})\end{array}$ & $\begin{array}{c}\text { Rail \% } \\
\text { by } \\
\text { Weight }\end{array}$ & $\begin{array}{c}\text { Water } \\
(\mathrm{km})\end{array}$ & $\begin{array}{c}\text { Water \% } \\
\text { by } \\
\text { Weight }\end{array}$ & $\begin{array}{c}\text { Air } \\
(\mathrm{km})\end{array}$ & $\begin{array}{c}\text { Air \% by } \\
\text { Weight }\end{array}$ \\
\hline Coal & 140 & 93 & $18 \%$ & 922 & $68 \%$ & 548 & $6 \%$ & 0 & $0 \%$ \\
\hline Fuel oils & 50 & 48 & $54 \%$ & 1232 & $1 \%$ & 0 & $0 \%$ & 0 & $0 \%$ \\
\hline $\begin{array}{c}\text { Other } \\
\text { petroleum } \\
\text { fuels }\end{array}$ & 158 & 122 & $68 \%$ & 1419 & $13 \%$ & 288 & $12 \%$ & 0 & $0 \%$ \\
\hline Chemicals & 1065 & 216 & $54 \%$ & 674 & $26 \%$ & 562 & $13 \%$ & 1034 & $0.1 \%$ \\
\hline $\begin{array}{c}\text { Logs and } \\
\text { wood }\end{array}$ & 296 & 165 & $98 \%$ & 1568 & $2 \%$ & 0 & $0 \%$ & 0 & $0 \%$ \\
\hline Pulp & 420 & 261 & $78 \%$ & 1502 & $22 \%$ & 0 & $0 \%$ & 0 & $0 \%$ \\
\hline $\begin{array}{c}\text { Waste and } \\
\text { scrap }\end{array}$ & 194 & 240 & $60 \%$ & 502 & $25 \%$ & 453 & $14 \%$ & 0 & $0 \%$ \\
\hline
\end{tabular}

\section{RESULTS AND DISCUSSION}

This study calculated that 79.5 million metric tons of $\mathrm{CO}_{2} \mathrm{eq}$ and an additional 104 million metric tons of biogenic $\mathrm{CO}_{2}$ were emitted from the US pulp and paper industry in 2018. Half of these $\mathrm{CO}_{2}$ eq emissions were from the production and combustion of fuels, with 95\% of those fuel GHG emissions being fossil-based and 5\% originating from biomass. The EPA calculated direct emissions data, including fuel combustion without biogenic $\mathrm{CO}_{2}$, from US mills and reported a total of 34 million tons of $\mathrm{CO}_{2}$ eq emissions per year (EPA 2017), which is close to the total GHG emissions from fuel combustion in this study (39.7 million metric tons of $\mathrm{CO}_{2}$ eq in 2018). The total GHG emissions calculated in this study (79.5 million metric tons of $\mathrm{CO}_{2} \mathrm{eq}$ ) were twice the value reported by the EPA due to the greater system boundary (inclusion of upstream emissions in the production of fuels and other inputs) of this research.

For comparison purposes, the average GHGI weighted by production volume for each product category was calculated, as summarized in Table 7. The Others category had the greatest GHGI (1978 $\mathrm{kg} \mathrm{CO}_{2}$ eq / metric ton of product), likely due to products in this category being specialty products, such as bible and grease-proof papers. These papers require more energy to produce, are smaller-scale, and are not co-located with a biomass boiler, as shown in the high amounts of fuel and electricity used, resulting in high GHGI values. Tissue suffers from the same issues and also has a high GHGI value. Low GHGI values were observed for products produced at large scale at one facility, with biomassderived energy being very prominent. 
Table 7. GHGI for all US Pulp and Paper Product Categories

\begin{tabular}{|c|c|c|c|c|c|c|c|c|}
\hline \multirow[b]{3}{*}{ Category } & \multirow{3}{*}{ 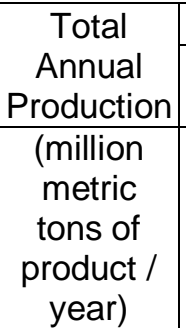 } & \multicolumn{6}{|c|}{ GHG Intensity } & \multirow{2}{*}{$\begin{array}{c}\text { Biogenic } \\
\mathrm{CO}_{2} \\
\text { Intensity }\end{array}$} \\
\hline & & Total & Fuel & $\begin{array}{l}\text { Electricity } \\
\text { Purchases }\end{array}$ & $\begin{array}{c}\text { Wood, } \\
\text { Upstream }\end{array}$ & $\begin{array}{l}\text { Chemicals, } \\
\text { Upstream }\end{array}$ & Transportation & \\
\hline & & \multicolumn{6}{|c|}{ ( $\mathrm{kg} \mathrm{CO}$ 2eq / metric ton of product) } & $\begin{array}{c}\left(\mathrm{kg} \mathrm{CO}_{2} /\right. \\
\text { metric } \\
\text { ton of } \\
\text { product })\end{array}$ \\
\hline US Total & 84.4 & 942 & 474 & 223 & 97 & 60 & 88 & 1232 \\
\hline UCGW & 1.3 & 608 & 227 & 168 & 114 & 45 & 55 & 271 \\
\hline CGW & 1.5 & 1511 & 1105 & 154 & 77 & 105 & 70 & 864 \\
\hline UCWF & 7.4 & 1148 & 651 & 181 & 115 & 102 & 99 & 1552 \\
\hline CWF & 3.0 & 1057 & 511 & 198 & 130 & 131 & 88 & 1749 \\
\hline BPB & 6.9 & 857 & 416 & 85 & 151 & 96 & 109 & 2131 \\
\hline UBPB & 22.5 & 714 & 355 & 111 & 115 & 43 & 89 & 1515 \\
\hline RPB & 18.8 & 691 & 421 & 176 & 14 & 25 & 55 & 255 \\
\hline $\mathrm{PP}$ & 2.5 & 1559 & 718 & 567 & 127 & 54 & 93 & 1313 \\
\hline Tissue & 8.4 & 1720 & 886 & 682 & 39 & 26 & 87 & 344 \\
\hline MP & 11.1 & 855 & 241 & 202 & 186 & 101 & 125 & 2253 \\
\hline Others & 1.0 & 1978 & 1063 & 667 & 60 & 75 & 114 & 785 \\
\hline
\end{tabular}

A considerable amount of biogenic $\mathrm{CO}_{2}$ is emitted by the pulp and paper industry. A visualization of Table 7 is provided in Fig. 1, showing that, for 5 of 11 categories, biogenic $\mathrm{CO}_{2}$ emissions exceeded fossil-based GHG emissions. This result was due to the industry's heavy use of bio-based fuels, particularly pulping liquor and waste wood. Together, these two fuels provided $64 \%$ of the energy consumption (excluding electricity) of the US pulp and paper industry, as shown in Fig. 2.

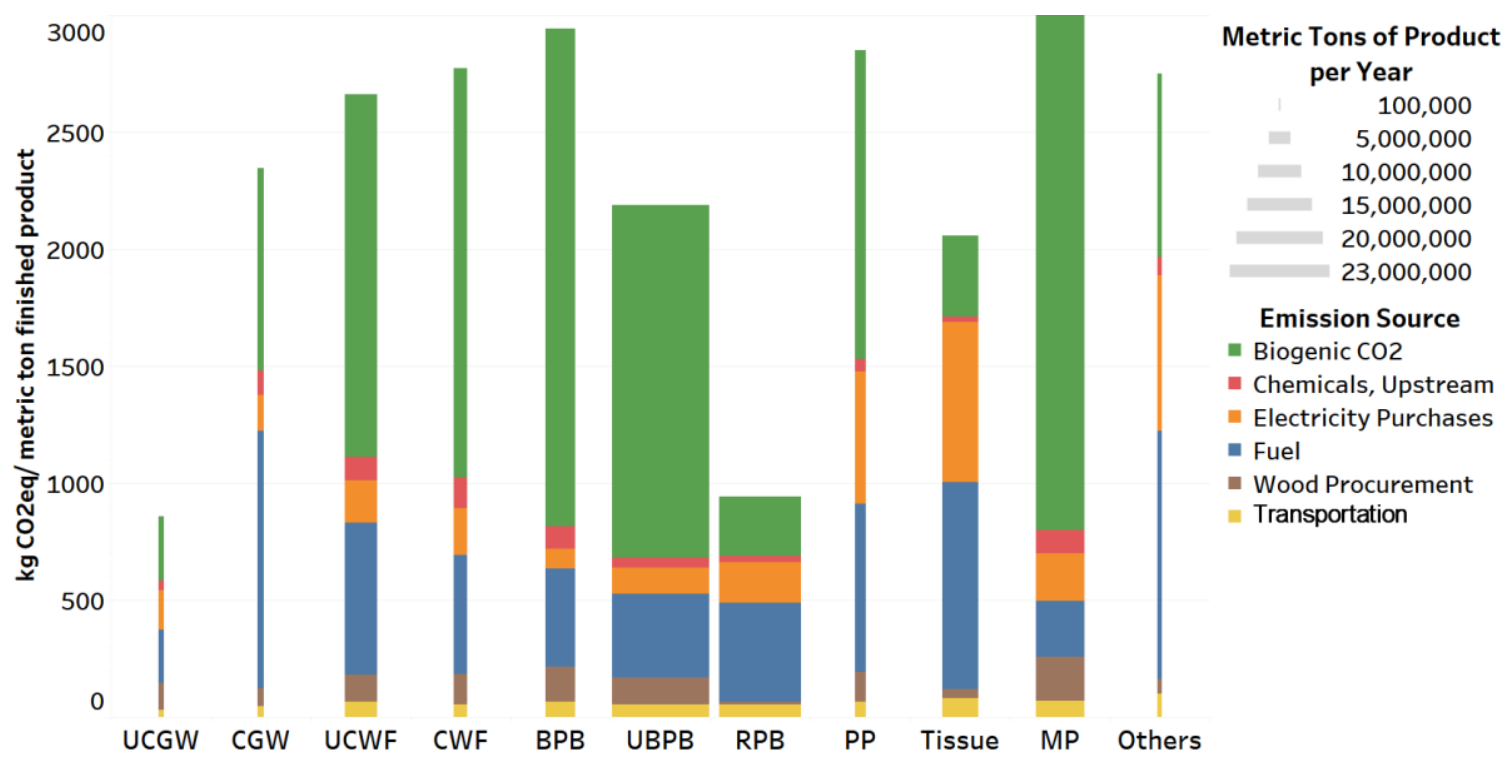

Fig. 1. GHGl sources and biogenic $\mathrm{CO}_{2}$ comparison for each product category

With the carbon neutrality assumption, these two fuels only account for $1.3 \%$ of total GHG emissions. As discussed previously, the emission factors of electricity and 
transportation were not differentiated at the mill level. However, such uncertainty may not have large impacts on the results for two reasons. First, Fig. 1 shows that transportation counts for only a small percentage (on average $4 \%$ across all product categories) of total GHG emissions. Second, GHG emission factors of electricity purchased have already been differentiated at the state level based on the location of each mill, and only two product categories (tissue and others) have significant GHG emissions from electricity purchases $(>20 \%)$.
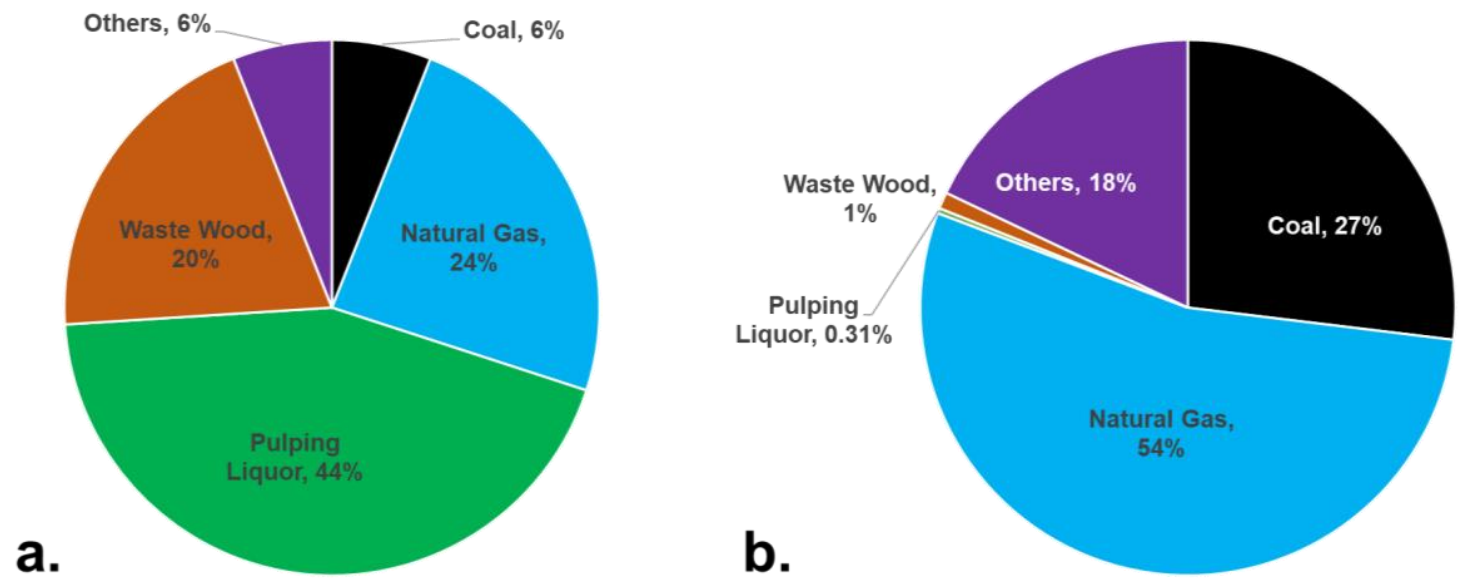

Fig. 2. (a) Energy consumption of the US pulp and paper industry by major fuel types and (b) GHG emissions of the US pulp and paper industry by major fuel types

For each paper category, the greatest contributor to GHG emissions was fuel, even with the heavy reliance on bio-based fuels and the exclusion of biogenic $\mathrm{CO}_{2}$. Natural gas alone was responsible for $54 \%$ of fuel GHG emissions industry-wide, with coal responsible for an additional $27 \%$ (Fig. 2). The proportions of fuel types used differed among the paper categories (Fig. 3), though all categories except UCGW mostly relied on coal and natural gas.

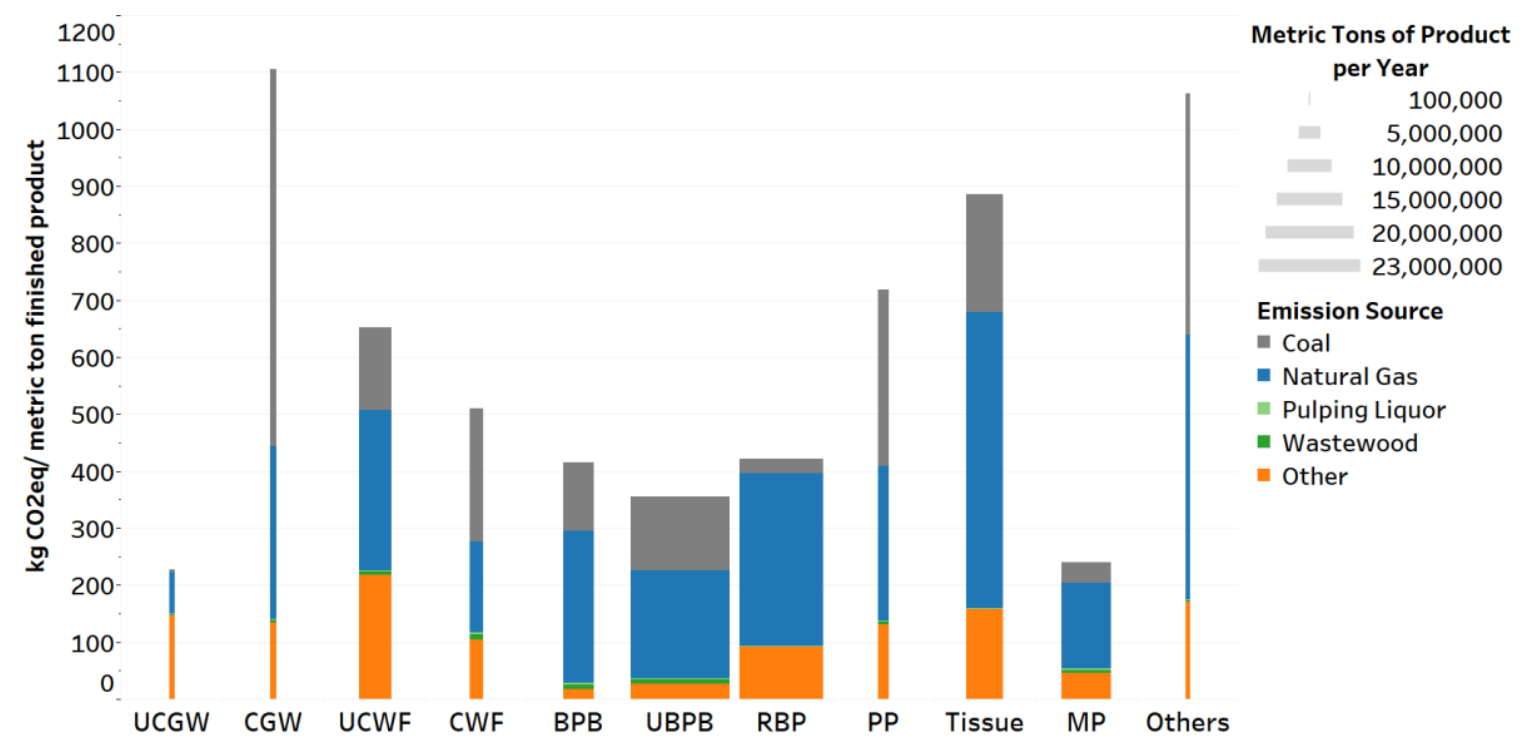

Fig. 3. Fuel GHGl for each paper category broken down by source, excluding biogenic $\mathrm{CO}_{2}$ 
Since fuel accounts for $50 \%$ of total GHG emissions, excluding biogenic $\mathrm{CO}_{2}$ for the US pulp and paper industry (Table 8), fuel switching could be a promising strategy for GHG reduction. Figure 4 illustrates the fuels' GHG emissions and costs on a per-heatingunit basis. The cost data were collected from FisherSolve (Fisher International 2018) and uses the average price paid by mills in the US in 2018. With the exceptions of biodiesel and biogas, most bio-based fuels used in 2018 by the pulp and paper industry were less expensive than fossil fuels on a per-heating-unit basis. However, two major bio-based fuels, pulping liquor and sludge, are byproducts/wastes of pulp and paper production and generally not sold in the market. Thus, their availability is subject to mill processes and technology, limiting the potential for fuel switching to these sources.

Table 8. Industry Total GHG Emission Contributors, Excluding Biogenic $\mathrm{CO}_{2}$

\begin{tabular}{|c|c|c|}
\hline Source & $\begin{array}{c}\text { Total GHG Emissions } \\
\left(\mathrm{kg} \mathrm{CO}_{2} \text { eq in 2018) }\right.\end{array}$ & $\begin{array}{c}\text { Percentage of Total GHG } \\
\text { Emissions }(\%)\end{array}$ \\
\hline Fuel & $3.97 \times 10^{10}$ & 50 \\
\hline Electricity & $1.90 \times 10^{10}$ & 24 \\
\hline Wood procurement & $7.95 \times 10^{9}$ & 10 \\
\hline Chemicals & $4.77 \times 10^{9}$ & 6 \\
\hline Transportation & $7.95 \times 10^{9}$ & 10 \\
\hline
\end{tabular}

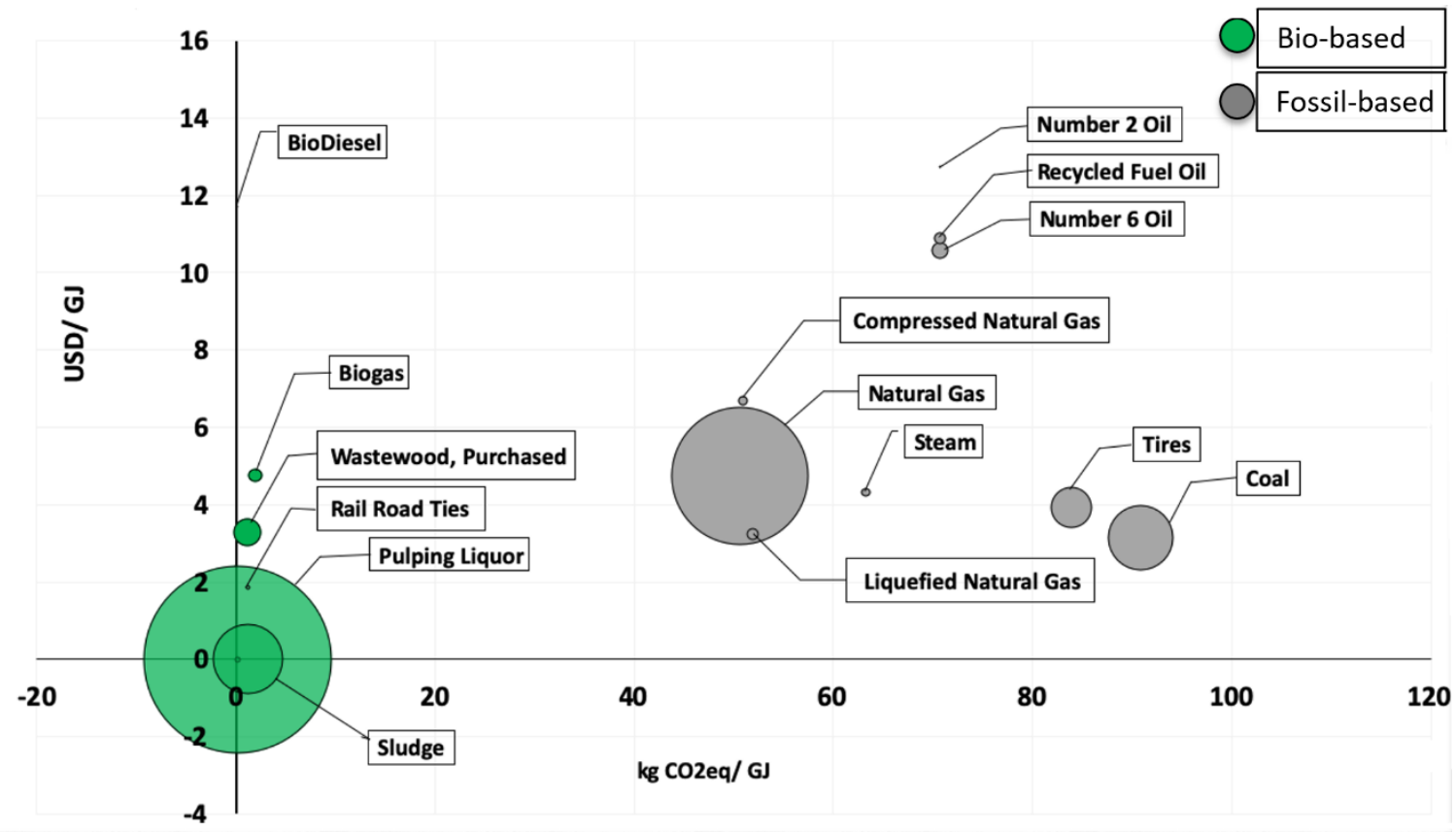

Fig. 4. Emission intensities and cost comparison for various fuels used in the US pulp and paper industry. Bubble size represents the relative use industry-wide.

In addition to the simple fuel-cost considerations, fuel-switching decisions must entail capital cost analyses of purchasing equipment, logistics, and operational issues that occur with using solid fuels relative to fluid fuels. These considerations need to be evaluated on a mill-by-mill basis, given the variability of mill processes and regional resources that exist in the United States. Both techno-economic analysis (TEA) and environmental LCA are powerful tools for mills to explore different fuel-switching options from both economic and environmental perspectives. More research is needed to better 
understand the tradeoffs of each fuel-switching option and to improve the technical applicability of low-carbon fuels in different pulp and paper production processes.

Emissions related to electricity purchases made up $24 \%$ of total GHG emissions by the US pulp and paper industry (Table 8), excluding biogenic $\mathrm{CO}_{2}$. Tissue had the greatest electricity GHGI, which reflects the high percentage $(68 \%)$ of mills that only buy pulp rather than producing it. Internal mill electricity production may be considered along with lower-emission fuels to decrease the GHG emissions of a manufacturing site.

Another pathway to reduce energy-related emissions is to improve energy efficiency, as emphasized by many previous studies, such as the Fifth Assessment Report of the IPCC (Möllersten et al. 2003; Fleiter et al. 2012; Myhre et al. 2013). For the pulp and paper industry, an energy study conducted by the US Department of Energy estimated an energy savings of $465 \mathrm{TBtu} / \mathrm{y}$ (491 PJ/y) nationwide by adopting the state-of-the-art technologies of pulping and papermaking and utility systems in which paper drying and the powerhouse, where steam and electricity are generated on-site, have the greatest energy-saving potential (Miller et al. 2015). Another international study indicated great energy-efficiency improvement opportunities by modifying wood digesters and improving steam production and distribution (Tam et al. 2009). However, these studies were sectorwide analyses. The implementation of specific technologies is highly mill-specific and will need a thorough investigation of economic feasibility, operating changes, and other potential benefits or disadvantages. More discussions regarding improving energy efficiency and reducing GHG emissions of pulp and paper production appear in Tomberlin (2019).

Fiber sources varied from mill to mill and were the third greatest contributor to the US pulp and paper industry's total GHGI, making up 10\% of industry-wide GHG emissions (Table 8), excluding biogenic $\mathrm{CO}_{2}$. Of the categories studied, RPB had the lowest GHGI from wood procurement, given that RPB is mostly produced from recycled fibers and only a small amount of wood is used to enhance the pulp. This study assigned zero GHG emissions to pulp purchases and recycled fibers to avoid double counting.

The upstream production of chemicals was another source of GHG emissions, composing 6\% of total industry GHG emissions in 2018 (Table 8), excluding biogenic $\mathrm{CO}_{2}$; the emissions were affected by the quantities and types of chemicals. Figure 5 shows GHG emissions broken down by the chemical types used in different processes. In general, the processes with the greatest GHG emissions from chemicals were coating, pulping, and bleaching. As a result, the coated papers (CGW and CWF) had greater chemical GHGIs than their uncoated counterparts (UCGW and UCWF), as shown in the chemical column of Table 7. Similarly, of the paperboard categories, RPB had the lowest chemical GHGI, as it lacks chemical pulping, while BPB had the highest, as it includes pulping and bleaching.

The last GHG contributor examined in this study was the transportation of fuel, wood, recycled fiber, pulp, and chemicals to the mill site. Transportation contributed $10 \%$ of the industry's total GHG emissions (Table 8), excluding biogenic $\mathrm{CO}_{2}$. This emission source had the smallest GHGI range among product categories. Market pulp, however, had the greatest transportation GHGI due to its heavy reliance on wood, which is transported with high moisture content. All other categories had some pulp purchases, which are shipped with a lower moisture content than wood. The high moisture content means that the wood is heavier than recycled materials or pre-made pulp on a per-mass-of-usable-fiber basis, and it requires more fuel for transportation.

Tomberlin et al. (2020). "Pulp \& paper GHG emissions," BioResources 15(2), 3899-3914. 3909 


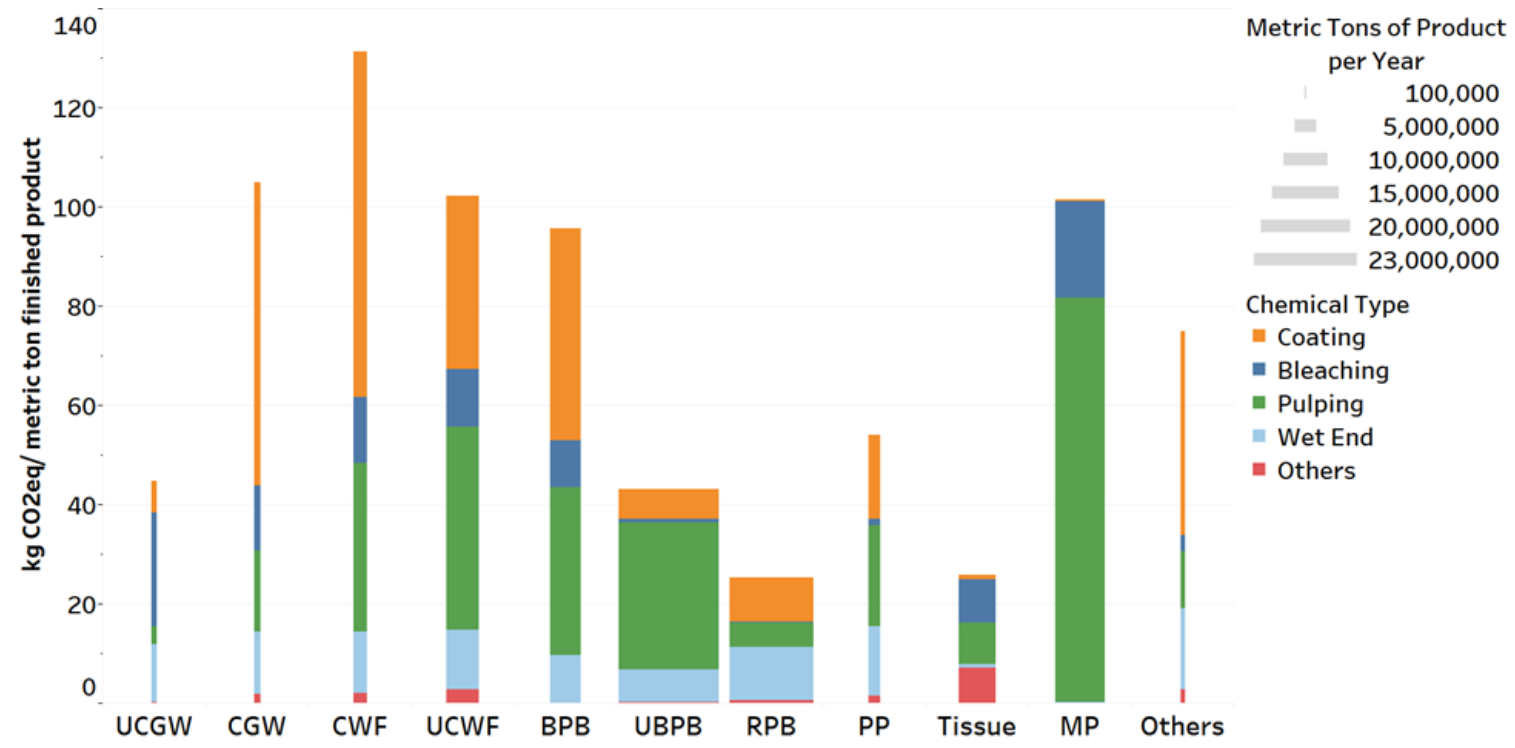

Fig. 5. Chemical GHGls for each paper category broken down by chemical type. Only upstream emissions from the production of each chemical were included. Table 3 lists the chemicals included in each type.

The above results have been expressed in averages for each product category, but product lines within a category vary. One unique contribution of this study was the investigation of such variations of mills within the same product categories. Table 9 shows the statistical summary for GHGIs of individual mills in the same product category. The variations of GHGI within each product category are very large (as demonstrated by the large differences between minimum and maximum, and large standard deviations, Table 9 ). However, most of the mills with high GHGI have low production volumes, as show in Fig. 6.

Table 9. Statistical Summary for GHGI of Each Category

\begin{tabular}{|c|c|c|c|c|c|c|}
\hline \multirow{2}{*}{ Category } & \multirow{2}{*}{$\begin{array}{c}\text { Number of } \\
\text { Product Lines } \\
\text { Represented }\end{array}$} & Minimum & Maximum & Average* $^{*} \begin{array}{c}\text { Standard } \\
\text { Deviation }\end{array}$ \\
\cline { 3 - 6 } & 16 & 201 & 6590 & 1210 & 1475 \\
\hline UCGW & 14 & 292 & 29920 & 3403 & 7386 \\
\hline CGW & 128 & 134 & 85630 & 2630 & 7967 \\
\hline UCWF & 29 & 319 & 12800 & 1763 & 2593 \\
\hline CWF & 37 & 276 & 20190 & 1479 & 3144 \\
\hline BPB & 55 & 293 & 3247 & 814 & 452 \\
\hline UBPB & 157 & 83 & 3778 & 3412 & 609 \\
\hline RPB & 76 & 537 & 44180 & 3963 & 6984 \\
\hline PP & 228 & 115 & 33800 & 2799 & 5268 \\
\hline Tissue & 86 & 421 & 20800 & 1931 & 3412 \\
\hline MP & 39 & 794 & 89820 & 7848 & 16820 \\
\hline Others & &
\end{tabular}

*The average in this table is arithmetic mean (not production weighted average). 


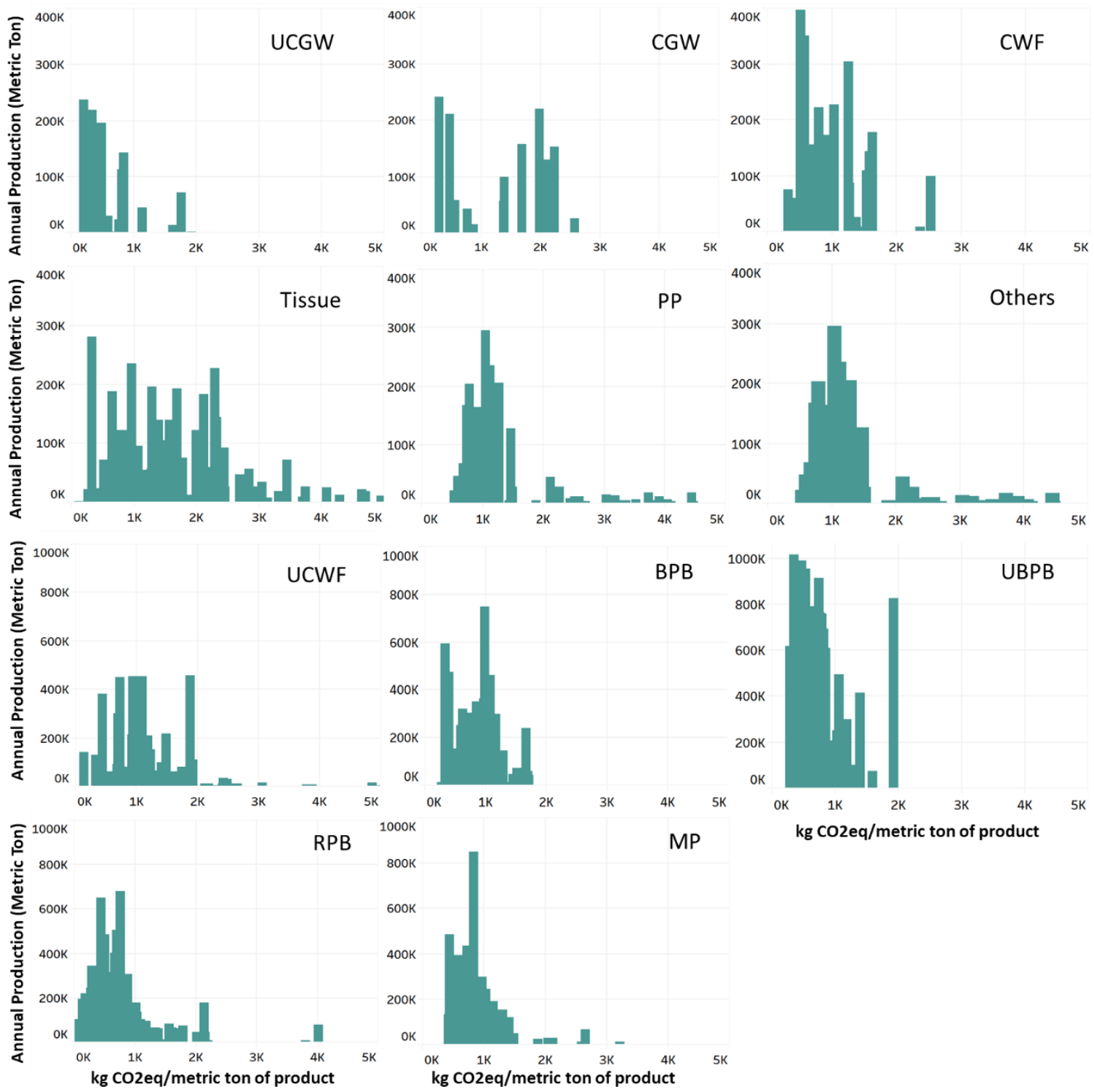

Fig. 6. GHGI distributions for each product category by production. Data over $5000 \mathrm{~kg} \mathrm{CO} \mathrm{CO}_{2} \mathrm{eq} /$ metric ton of product were excluded for figure readability and they make up less than $5 \%$ of data points and total production. $\mathrm{K}=1000$.

GHGI values larger than $5000 \mathrm{~kg} \mathrm{CO}_{2} /$ metric ton of product were excluded in Fig. 6 , as those mills contributed to less than $5 \%$ of total production of each product category and were considered as outliers. Those outliers significantly raised the arithmetic mean and standard deviation of each category (shown as average in Table 9), but their impacts were highly diluted when production volume is considered (which is why the weighted averages shown in Table 7 are much smaller than the arithmetic means in Table 9).

In general, Fig. 6 shows that product categories with smaller production volume (UCGW, CGW, CWF, Tissue, PP, Others, production < 400,000 metric ton/year) have wider distributions than product categories with larger production volume (UCWF, BPB, UBPB, RPB, MP, production >400,000 metric ton/year). This could be due to wider varieties of product types, production methods, and fuel compositions for smaller mills, those mills may have more opportunities for GHG emission reductions. For larger mills, 
there may be less room for GHG emission reductions that may exist with products that have high tails or high outliers.

\section{CONCLUSIONS}

1. From cradle to gate, the production volume weighted average metric ton of pulp and paper product in the US produced $942 \mathrm{~kg} \mathrm{CO}_{2} \mathrm{eq}$.

2. The source breakdown of total GHG emissions of the US pulp and paper industry was as follows: fuels $50 \%$, electricity $24 \%$, wood procurement $10 \%$, transportation $10 \%$, and chemicals $6 \%$.

3. The GHGI varied greatly between and within paper categories due to differences in production methods and energy-use structures.

4. Distributions showing GHGI variances within product categories revealed some categories having much smaller spreads (CGW, CWF, BPB, and UBPB) than others (Tissue, PP, and MP). Wider spreads were likely due to varieties of production methods, fuel compositions, and products within each category.

5. More biogenic $\mathrm{CO}_{2}$ was emitted by the US pulp and paper industry than all other GHG emissions combined.

\section{ACKNOWLEDGMENTS}

The authors are grateful for the support of the USDA-NIFA project "Preparing Diverse and Rural Students to Meet the Challenges in the Bioproducts and Bioenergy Industry," Award No. 2017-67009-26771.

\section{REFERENCES CITED}

AF\&PA (2011). Printing \& Writing Papers: Life-cycle Assessment Summary Report, The American Forest \& Paper Association, Washington, DC, USA.

Bright, R. M., Cherubini, F., and Strømman, A. H. (2012). "Climate impacts of bioenergy: Inclusion of carbon cycle and albedo dynamics in life cycle impact assessment," Environmental Impact Assessment Review 37. DOI: 10.1016/j.eiar.2012.01.002

BTS and U.S. Census Bureau (2015). 2012 Commodity Flow Survey (Report No. EC12TCF-US), U. S. Department of Transportation, Bureau of Transporation Statistics, Washington, DC, USA, and U. S. Department of Commerce, U. S. Census Bureau, Suitland, MD, USA.

Cherubini, F., Bright, R. M., and Strømman, A. H. (2012). "Site-specific global warming potentials of biogenic $\mathrm{CO}_{2}$ for bioenergy: Contributions from carbon fluxes and albedo dynamics," Environmental Research Letters 7(4). DOI: 10.1088/17489326/7/4/045902

Daystar, J., Venditti, R., and Kelley, S. S. (2017). "Dynamic greenhouse gas accounting for cellulosic biofuels: Implications of time based methodology decisions," The 
International Journal of Life Cycle Assessment 22(5), 812-826. DOI:

10.1007/s11367-016-1184-8

EPA (1995). Compilation of Air Pollutant Emission Factors (Report No. AP-42), United States Environmental Protection Agency, Washington, DC, USA.

EPA (2016). Emissions \& Generation Resource Integrated Database (eGRID), United States Environmental Protection Agency, Washington, DC, USA.

EPA (2017). "GHGRP pulp and paper," Greenhouse Gas Reporting Program (GHGRP), (https://www.epa.gov/ghgreporting/ghgrp-pulp-and-paper), Accessed March 2019.

EPA (2018). Emission Factors for Greenhouse Gas Inventories, United States Environmental Protection Agency, Washington, DC, USA.

Fischedick, M., Roy, J., Abdel-Aziz, A., Acquaye, A., Allwood, J., Ceron, J.-P., Geng, Y., Kheshgi, H., Lanza, A., Perczyk, D., et al. (2014). "Industry," in: Climate Change 2014: Mitigation of Climate Change. Working Group III Contribution to the Fifth Assessment Report of the Intergovernmental Panel on Climate Change, O. Edenhofer, R. Pichs-Madruga, Y. Sokona, J. C. Minx, E. Farahani, S. Kadner, K. Seyboth, A. Adler, I. Baum, S. Brunner, et al. (eds.), Intergovernmental Panel on Climate Change, Geneva, Switzerland.

Fisher International (2018). "FisherSolve database," (https://www.fisheri.com/productsservices/fishersolve/), Accessed 6 Feb 2019.

Fleiter, T., Fehrenbach, D., Worrell, E., and Eichhammer, W. (2012). "Energy efficiency in the German pulp and paper industry - A model-based assessment of saving potentials," Energy 40(1), 84-99. DOI: 10.1016/j.energy.2012.02.025

Ishikawa, S., Hoshiba, S., Hinata, T., Hishinuma, T., and Morita, S. (2006).“Evaluation of a biogas plant from life cycle assessment (LCA)," International Congress Series 1293, 230-233. DOI: 10.1016/j.ics.2006.02.008

ISO, 2006. ISO 14040:2006 Environmental management- Life cycle assessmentPrinciples and framework.

Levasseur, A., Lesage, P., Margni, M., and Samson, R. (2012). "Biogenic carbon and temporary storage addressed with dynamic life cycle assessment," Journal of Industrial Ecology 17(1), 117-128. DOI: 10.1111/j.1530-9290.2012.00503.x

Masson-Delmotte, V., Zhai, P., Pörtner, H.-O., Roberts, D., Skea, J., Shukla, P. R., Pirani, A., Moufouma-Okia,W., Péan, C., Pidcock, R., et al. (eds.) (2018). Global Warming of $1.5^{\circ} \mathrm{C}$ : An IPCC Special Report on the Impacts of Global Warming of $1.5^{\circ} \mathrm{C}$ above Pre-industrial Levels and Related Global Greenhouse Gas Emission Pathways, in the Context of Strengthening the Global Response to the Threat of Climate Change, Sustainable Development, and Efforts to Eradicate Poverty, Intergovernmental Panel on Climate Change, Geneva, Switzerland.

Miller, T., Kramer, C., and Fisher, A. (2015). Bandwidth Study on Energy Use and Potential Energy Saving Opportunities in U.S. Pulp and Paper Manufacturing, U.S. Department of Energy, Office of Energy Efficiency \& Renewable Energy, Washington, DC, USA.

Möllersten, K., Yan, J., and Westermark, M. (2003). "Potential and cost-effectiveness of $\mathrm{CO}_{2}$ reductions through energy measures in Swedish pulp and paper mills," Energy 28(7), 691-710. DOI: 10.1016/S0360-5442(03)00002-1

Myhre, G., Shindell, D., Bréon, F.-M., Collins, W., Fuglestvedt, J., Huang, J., Koch, D., Lamarque, J.-F., Lee, D., Mendoza, B., et al. (2013). "Anthropogenic and natural radiative forcing," in: Climate Change 2013: The Physical Science Basis. Working Group I Contribution to the Fifth Assessment Report of the Intergovernmental Panel 
on Climate Change, T. F. Stocker, D. Qin, G.-H. Plattner, M. M. B. Tignor, S. K. Allen, J. Boschung, A. Nauels, Y. Xia, V. Bex, and P. M. Midgley (eds.), Intergovernmental Panel on Climate Change, Geneva, Switzerland.

Nabinger, A., Tomberlin, K., Venditti, R., and Yao, Y. (2019). "Using a data-driven approach to unveil greenhouse gas emission intensities of different pulp and paper products," Procedia CIRP 80, 689-692. DOI: 10.1016/j.procir.2018.12.001

National Renewable Energy Laboratory (2015). "U.S. life cycle inventory database," (https://www.nrel.gov/lci/), Accessed November 20, 2019.

RISI (2018). "Fastmarkets RISI annual review 2018," (https://www.risiinfo.com/), Accessed 18 April 2019.

Tam, C., Baron, R., Gielen, D., Taylor, M., Taylor, P., Trudeau, N., Patel, M., and Saygin, D. (2009). Energy Technology Transistions for Industry: Strategies for the Next Industrial Revolution, International Energy Agency, Paris, France.

TAPPI TIP 0404-36 (2013). "Paper grade classifications," TAPPI Press, Atlanta, GA, USA.

Tomberlin, K. E. (2019). Life Cycle Carbon Analysis of US Pulp and Paper Grades Using Self-reported Mill Data, Master's Thesis, North Carolina State University, Raleigh, NC, USA.

Triantou, A.-D. (2009). Carbon, Energy and Water Footprint of Three AkzoNobel Internal Sizing Chemicals: A Cradle to Gate LCA Related Study, Master's Thesis, Royal Institute of Technology, Stockholm, Sweden.

Wernet, G., Bauer, C., Steubing, B., Reinhard, J., Moreno-Ruiz, E., and Weidema, B. (2016). "The ecoinvent database version 3 (part I): Overview and methodology," The International Journal of Life Cycle Assessment 21(9), 1218-1230. DOI: 10.1007/s11367-016-1087-8

Zabaniotou, A., and Kassidi, E. (2003). "Life cycle assessment applied to egg packaging made from polystyrene and recycled paper," Journal of Cleaner Production 11(5), 549-559. DOI: 10.1016/S0959-6526(02)00076-8

Zhang, L. X., Wang, C. B., and Song, B. (2013). "Carbon emission reduction potential of a typical household biogas system in rural China," Journal of Cleaner Production 47, 415-421. DOI: 10.1016/j.jclepro.2012.06.021

Article submitted: September 5, 2019; Peer review completed: February 13, 2020;

Revised version received: March 24, 2020; Accepted: March 29, 2020; Published: April 7, 2020.

DOI: 10.15376/biores.15.2.3899-3914 